DOI: 10.46340/ephd.2021.7.1.18

\author{
Valentina Rozhkovska \\ ORCID ID: https://orcid.org/0000-0001-8779-4912 \\ Odessa I.I. Mechnikov University, Ukraine

\section{"REALITY" AND THE CONCEPT \\ OF PHYSICAL REALITY IN THE TEXTS \\ OF A. EINSTEIN}

\author{
Валентина Рожковська \\ Одеський національний університет ім. І.І.Мечникова, Україна

\section{«РЕАЛЬНІСТЬ» І ПОНЯТТЯ ФІЗИЧНОЇ РЕАЛЬНОСТІ В РОБОТАХ А. ЕЙНШТЕЙНА}

The article is aimed at finding out how Einstein's scientific discoveries are connected with an understanding of what reality is. The discoveries of the outstanding scientist affected not only physics, but also other sciences. The author is trying to show that the consequence of Einstein's work was a rethinking of fundamental physical categories, which in turn led to changes in ideas about reality. These discoveries brought Einstein to the philosophical level of rethinking old problems. The author notes that changes in ideas about reality arose even before the advent of quantum theory. Here, Einstein acts as a historian of physics and points out that the discovery of a magnetic and electric field led to these changes. However, if the fields have expanded understanding of reality, than quantum theory changes this idea at a fundamental level. According to the scientific theory of the time, the reality is that which corresponds to sensation. Therefore, the magnetic and electric fields become reality, because they can be fixed with the help of devices. However, quantum theory makes a change to the basic principles on which scientific knowledge is built. Einstein devoted a huge part of his life to the search for the so-called "unified theory". The goal of this theory was to combine various physical data into a single, non-contradictory theory. This would make it possible to say that physics has found a concept that describes reality. Analyzing various texts of Einstein, the author claims that the question of reality becomes important in the context of a dispute with another major scientist - N. Bohr. The creator of the theory of relativity puts forward his criterion for theories that claim to describe reality. Despite the successes of quantum theory, it cannot adequately describe reality from the point of view of Einstein. However, Einstein is not able to build a theory that includes all physical knowledge. The author of the article points to characteristics that must satisfy a theory that claims to be a complete description of reality from Einstein's point of view. The author indicates why quantum theory does not satisfy these very criteria.

Keywords: reality, theory of relativity, Copenhagen school, quantum physics, science

У науці періодично зустрічаються досягнення, що виходять за межі самої цієї науки. Чим суворіші іiі межі, тим глибше виявляється проникнення у фундаментальні області людських знань. У такі моменти виникає необхідність осмислення отриманих загальнонаукових досягнень. Тут на допомогу приходить філософія. Прикладом наукових результатів, які осмислюються в філософії, можуть служити відкриття зроблені Альбертом Ейнштейном. Наслідком його робіт став перегляд фундаментальних фізичних категорій, що у свою чергу призвело до змін уявлень про реальність. 3 точки зору філософії важливо, яким було поняття про реальність в науці до відкриттів Альберта Ейнштейна, і що змінилося з появою теорії відносності.

Про Ейнштейна написано дуже багато робіт, проте більшість 3 них присвячені науковій складовій його творчості. Все ж ряд дослідників займалися і філософськими проблемами, які ставила фізика Ейнштейна. Найчастіше ці дослідження стосувалися його полеміки з іншим великим фізиком - Нільсом Бором. Ця суперечка прямо стосувалась питання про природу реальності, але 
все-таки не це питання виявлявся центральним. Потрібно враховувати, що проблематика протистояння двох великих фізиків торкалась відкриття (і висновків), зроблених в квантовій теорії, але не в теорії відносності. 3 робіт філософів, які звернулися до аналізу концепції Ейнштейна, слід зазначити статтю Хосе Ортега-і-Гасет «Історичний сенс теорії Ейнштейна», а також невелику роботу Ернста Кассірера «Теорія відносності Ейнштейна». Окремі питання філософського осмислення можна знайти у збірнику статей «Ейнштейн і філософські проблеми фізики XX століття» і книзі «Ейнштейн i розвиток фізико-математичної думки». Треба сказати, що в XXI столітті тема розбіжностей між Ейнштейном та Бором набула особливої популярності. Про це свідчить стрімке зростання сучасної науково-популярної літератури, яка так чи інакше стосується спору між двома великими фізиками XX століття. 3 робіт недавнього часу, предметом якої стали тонкощі квантової теорії і неприйняття їі Ейнштейном, варто відзначити книгу М. Кумар «Квант. Ейнштейн, Бор і велика суперечка про проблему реальності». Також особливо варто виділити недавню роботу Уолтера Айзенксона «Ейнштейн. Його життя i його Всесвіт». У радянській філософській науці, де саме філософська сторона концепції німецького фізика виявлялася в центрі уваги і критики, варто перш за все назвати роботи В.Г.Кузнецова. Йому належить і біографія, в якій автор прагне не тільки розповісти про особу свого героя, а й дати філософський аналіз нової фізики з позиції марксизму.

Але навіть у тих роботах, де заходить мова про філософські позиції Ейнштейна або вчинений ним революційний переворот у наших уявленнях про світ навколо нас, питання про те, що таке реальність і як їі розуміти, піднімається не часто. Ця проблема іноді виникає лише в контексті спору Ейнштейна 3 копенгагенської школою фізиків. Деякі з робіт останнього часу стосуються питання про нове розуміння реальності у зв'язку з відкриттями Ейнштейна, але найчастіше ці роботи звертаються до досягнень фізики вже XXI століття. Ми бачимо завдання даної статті в тому, щоб встановити, яке уявлення про реальність лежить в основі робіт А. Ейнштейна, і тут особливо важливою постає його полеміка з копенгагенської школою фізиків.

Необхідно відзначити, що наукова спадщина Ейнштейна досить велика. Вона торкається широкого кола проблем, що не так часто зустрічаються серед фізиків, більшість з яких обмежуються суто спеціальними питаннями. У Ейнштейна цілий ряд статей стосується питань філософії науки, а не теоретичної фізики. У радянському виданні зібрань творів німецького фізика роботи, присвячені проблемам науки, зібрані головним чином в четвертому томі («Статті, рецензії та листи», 1967 рік). Саме у статтях «Вплив Максвелла на розвиток уявлень про фізичну реальність», «Про сучасну кризу в теоретичній фізиці», «Механіка Ньютона і iі вплив на формування теоретичної фізики», «Фізика і реальність» і ін, періоду 1922-1936 років виникає тема реальності, тому наш інтерес звернений до них у першу чергу.

Аналіз вживання терміну «реальність» в текстах Ейнштейна показує, що вчений використовує його досить часто. Виходячи з контексту, значення терміну в його працях в цілому відповідає науковому розумінню XX століття: реальність - це об'єктивно даний у відчуттях світ. Питання для фізика полягає в тому, як саме ця реальність влаштована, інакше кажучи, за якими законами працює сприйманий нами світ. Характерною рисою робіт Ейнштейна, про яку ми повинні пам'ятати, є його інтерес до історії фізики $\mathrm{i}$, описуючи ii розвиток, він неодноразово висував думку, що зміна в розумінні реальності виникла ще до появи квантової теорії ${ }^{1}$. Традиційна історія науки відправною точкою в описі реальності вважає фізику Ньютона (іноді Галілея, не протиставляючи їх). Класичній механіці вдалося зібрати воєдино і описати закони існуючого світу математичною мовою. Це дало можливість говорити про створення фундаментальної теорії, яка описує реальність. Така модель залишалася незмінною протягом кількох століть, практично без змін у фундаментальних питаннях, розвивалися лише окремі галузі фізичної науки. В автобіографічних нотатках 1949 Ейнштейн пише: «У теорії Ньютона реальність уявлялася матеріальними точками і в просторі, і в часі...» ${ }^{2}$. Це дуже важливий момент. Перший ступінь у науці Нового часу при описі реальності відводився матеріальним точкам. Практично для всіх розділів фізики, незважаючи на різноманітність, їх об'єкти можна було звести до матеріальних точок (точок у просторі та часі). Поведінка абсолютно всіх матеріальних точок виражалося законами класичної механіки і описувалося математичною мовою. Саме математичний опис дозволяв говорити про науковість тих чи інших законів. Ньютон, можна

\footnotetext{
1 Эйнштейн, А. (1967). Собрание научных трудов в четырех томах. Москва: Наука, 56, 86.

2 Там само, 289.
} 
сказати, створив «шифр» розуміння світу. Навіть якщо світ створений Богом, то виходить, Ньютон перший дав мову для опису того, за якими законами працює творіння Бога.

Ейнштейн повністю поділяє традиційне розуміння англійського фізика. Він також звертає увагу на те, що з розвитком фізики був виявлений феномен, який неможливо звести до матеріальних точок. Мова йде про електромагнітні поля, описанні Дж. К. Максвеллом. Хоча ще Фарадей проводив експерименти, які показують зв'язок між електрикою і магнетизмом, але тільки Максвелл їх описав математично, що дало підставу говорити про нові об'єкти реальності. У статті «Вплив Максвелла на розвиток уявлень про фізичну реальність» ${ }^{1}$ Ейнштейн у самій назві розкриває наступний крок науки в трансформації терміну, який нас цікавить. Наведемо фрагмент цієї статті: «Після Максвелла фізична реальність мислилася у вигляді безперервних, що не піддаються механістичному поясненню, полів, які описуються диференціальними рівняннями в частинах творах» ${ }^{2}$. Відзначимо, що Ейнштейн тут і далі розуміє реальність як існуючий фізичний світ. Але він вказує на відкриття нових об'єктів реальності - полів, які не зводяться до матеріальних точок подібно до того, як зводилися до них далі всі інші об' єкти фізики. Поява нової галузі знань призвела до руйнування цілісності у фізиці, оскільки тепер виявилося неможливим всю іiі звести до матеріальних об'єктів. Розуміння реальності в науці стає не таким однозначним. І цей факт Ейнштейн підкреслює в цілої низці статей. Наприклад, у роботі «Про сучасний кризу в теоретичній фізиці» 1922 Ейнштейн стверджує: «Згідно 3 концепцією Фарадея, поряд з матеріальною точкою та їі рухом з'явилася нового роду фізична реальність, а саме поле» ${ }^{3}$. I це далеко не єдиний приклад ${ }^{4}$.

Але по-справжньому битва за розуміння реальності розкинулася в суперечках з однією 3 революційних теорій, сформованих у XX столітті- квантовою механікою. Ейнштейн нерідко звертається до терміну «реальність», коли веде полеміку з Н. Бором про змістовну сторону квантової теорії. Відомо, що Ейнштейн довгий час скептично ставився до цього новому руху в фізиці. Однак квантова механіка показала свою ефективність на практиці, що привернуло до неї багато прихильників. Але для Ейнштейна це означало лише, що існує певна область фізики, яка працює за законами квантової механіки. Для нього цього було недостатньо, щоб претендувати на фундаментальну, універсальну теорію. Чому так сталося? Справа в тому, що, описуючи одну частину фізичного світу, квантова механіка вступає в протиріччя з уже сформованою, так званою, класичною фізикою (фізикою, якою вона стала вже після Максвелла і Резерфорда, тобто після тієї революції, про котру говорив Ейнштейн). 3 його точки зору, оскільки квантова механіка працює лише щодо певних об'єктів (мікрочастинок), вона може описувати лише одну з граней існуючого світу. Крім того, Ейнштейна не влаштовувало не тільки не узгодженість нової теорії з класичною фізикою, а й сама природа квантової механіки. Один з ключових постулатів квантової механіки - визнання, що на мікрорівні передбачення поведінки об'єкта можливе лише з певною часткою ймовірності. Ейнштейн визнавав, що квантова механіка успішно описує поведінку мікрочастинок за допомогою відмінних від класичної механіки законів. Але він оцінював цей факт як нездатність точного опису експерименту і пояснював його недостатньою кількістю даних. Альберт Ейнштейн був категорично проти того, щоб визнати, що неможливість прораховування поведінки частинки обумовлено самою природою реальності. Висновки 3 квантової механіки змушували думати, що у частинки немає законів, за якими вона рухається, вона з рівним ступенем імовірності може вести себе по-різному. Для класичної фізики такий висновок $є$ непорозумінням. Існує причина й існує слідство. I це фундаментальний закон світу. Якщо ми не можемо простежити причину, значить у нас недостатньо даних. Квантова механіка стверджує, що ми не можемо простежити причину поведінки об'єкта тому, що iii просто немає. Це стало камінням спотикання для Ейнштейна в його неприйнятті теорії. Наведемо кілька прикладів.

У статті «Вплив Максвелла на розвиток уявлень про фізичну реальність» 1931 року народження Ейнштейн пише: «Насправді, величини, які виступають в їі [квантової механіки] основних законах, не претендують на те, щоб описувати саму фізичну реальність, вони описують тільки ймовірність появи фізичної реальності» ${ }^{5}$. У цьому фрагменті Ейнштейн наполягає, що ймовірність появи фізичної реальності (якогось явища в реальності) ще не сама реальність. Реальність виключає довільність, в ній

\footnotetext{
1 Там само, 601.

2 Там само, 138.

${ }^{3}$ Там само, 86.

4 Там само, 56, 169.

5 Там само, 139.
} 
все визначається деякими причинами. Саме вони повинні пояснювати, чому в одному випадку об'єкт повівся таким чином, а в іншому - іншим.

3 аналізу аргументів Ейнштейна щодо заперечення того, щоб назвати квантову механіку повною, ми можемо швидше сказати, якою реальність, згідно з Ейнштейном, не повинна бути. Ключовий висновок із квантової механіки (описаний в принципі невизначеності Гейзенберга) Ейнштейн не приймав до кінця життя, і саме він став предметом багаторічних дискусій між ним i Бором. (Біографи розповідають, що коли Бора знайшли мертвим у його кабінеті, на його дошці були креслення: він до останніх годин займався перевіркою аргументів Ейнштейна.)

Ряд дослідників стверджує, що авторитет Ейнштейна і неприйняття ним нової концепції сприяло розвитку квантової механіки, адже потрібно дати відповідь на заперечення найбільшого фізика сучасності. 3 іншого боку, Ейнштейн і сам пише, що залишився практично на самоті, його точка зору не мала великої підтримки серед професіоналів. Втім Ейнштейн нове віяння в фізиці називав «модою».

Повернемося до статті 1931 року. Ейнштейн підкреслює, що квантова механіка говорить про ймовірності появи фізичної реальності, а не про неї саму. Для Бора реальність була саме такою. Раз математика квантової механіки дає висновки про ймовірності, значить це обумовлено природою самого об'єкта. Для Ейнштейна такий стан справ є неможливим. Імовірність не може відповідати реальності. Чому? Великий вчений докладно відповідає на це питання у статті, написаній у співавторстві з Б.Подільським і Н.Розеном. Автори статті пропонують ввести критерії, за якими фізичну теорію (механіку, електромагнітну або іншу) можна назвати повною, тобто ту, що охоплює реальність такою, яка вона є цілком: «...кожен елемент у фізичній реальності повинен мати відображення у фізичній теорії» ${ }^{1}$. Що це означає? У механіці Ньютона, якщо ми хочемо виміряти такі елементи реальності як вага, розмір, щільність яблука та інше, у нас повинен бути математичний апарат, який точно описує ці фізичні параметри. Якщо математика і експеримент не суперечать один одному, теорію можна вважати адекватно описуючий світ, i, що найголовніше, (особливо для Ейнштейна) в повному обсязі. Що відбувається в квантовій механіці? Введений Гейзенбергом принцип невизначеності стверджує, що за умови точного опису однієї координати елемента, ми не можемо описати іншу і навпаки. Ейнштейн не приймає цього твердження. Якщо теорія свідомо не може описати якийсь параметр, то він або не є реальним, або теорія описує реальність не повністю. Ейнштейн згоден визнати, що квантова механіка дає свої результати, але зазначений їм нюанс змушує думати, що необхідний пошук нової теорії, яка проллє світло на «чорні плями». Тут важлива річ його розбіжності з поглядами Бора, оскільки останній вважав, що реальність саме така: вона залишає місце для ймовірності, а тому квантова механіка описує те, як йде саме стан справ i, отже, пошуку нових теорій не вимагає.

Як ми вже відзначали, старе розуміння реальності змінилося ще з відкриттям електричного i магнітного полів, але квантова механіка нав'язувала більш радикальні зміни. Електромагнітна теорія вносила в фізику новий об'єкт: до матеріальних точок у просторі та часі додавалося поле, яке, незважаючи на його фізичну реальність, не можна звести до матеріальних об'єктів. У квантовій механіці не додають нові об'єкти реальності, а змінювалися закони, за якими влаштований сама реальність, і все.

В особистих нотатках Ейнштейн визнавав, що аргументи Бора вагомі, і можливо вони мають рацію, але, за власним висловом Ейнштейна, такий стан справ дуже сильно суперечить його науковому чуттю. Цей вислів набув широкої популярності. Дослідник Ягдім Miра в книзі «Einstein, physics and reality» називає таку схильність вподобанням (preference) і вважає, що саме це вподобання обумовлює фізику схилятися до закону причинності: «It has often been stated that his view was connected with preference for continuity and causality» ${ }^{2}$.

Варто відзначити, що квантова механіка мала ще одне неприйнятне для Ейнштейна положення. Він не міг погодитися $з$ тим, що спостерігач може вносити корективи в саму реальність. Проблема полягала в тому, що в експериментах на мікрорівні можна було уникнути впливу приладів на результати експериментів. Сучасний біограф Ейнштейна Улотер Айзексон стверджує, що «реальність Ейнштейна» володіє такими якостями, як відсутність впливу спостерігача, суворе

\footnotetext{
${ }^{1}$ Фок, В. А., Эйнштейн, А., Подольский, Б. А. (1936). Можно ли считать, что квантово-механическое описание физической реальности является полным? Успехи физических наук, 440. DOI: 10.3367/UFNr.0016.193604b.0436. 2 Jagdish, M. (2000). Einstein physics and reality. World Scientific, 128.
} 
дотримання закону причинності і локалізованість тіл в часі та просторі ${ }^{1}$. Суперечка з Бором, таким чином, змусила Ейнштейна прояснити його погляд на те, якою реальність не повинна бути.

Сам Ейнштейн все життя прагнув до створення цілісної картини світу, але відкриття нових об'єктів фізики змусило його задуматися, як можна повернути фізиці єдиний фундамент. Якщо раніше вся фізика грунтувалася на механіці, то тепер перед Ейнштейном стояло завдання знайти нову підставу.

Який внесок в розуміння реальності внесли досягнення самого Ейнштейна у фізиці? Характерно, що термін «реальність» набагато рідше зустрічається в його текстах, коли він говорить про теорію відносності, ніж коли про квантову теорію. У статті, яку ми вже згадали, «Про сучасній кризі в теоретичній фізиці», Ейнштейн повертається до електромагнітної теорії: «Останнім кроком в здійсненні програми теорії поля $є$ загальна теорія відносності» ${ }^{2}$. I далі він пише: «Простір і час були позбавлені, таким чином, не своєї реальності, а своєї казуальної абсолютності (що впливає, але не піддається впливу), яку змушений їм приписувати Ньютон для того, щоб отримати можливість висловити відомі тоді закони» ${ }^{3}$. Альберт Ейнштейн зміг встановити, що простір і час не є універсальною константою. Раніше абсолютність і незмінність простору і часу вважалася фундаментальною рисою реальності, такий стан справ існував принаймні до часів Ньютона. Кант називав простір і час апріорними формами чуттєвості. Працюючи з рівняннями Максвелла, Ейнштейн здогадався, що якщо швидкість світла в цих рівняннях виявляється незмінною, то повинні змінюватися рух часу і простору. Подальші багаторічні розрахунки привели його до висновку, що час залежить від швидкості об'єкта, причому з якою б швидкістю об'єкт не рухався. Але в повсякденному світі швидкості пересування об'єктів настільки малі, що зміни плину часу не помітні спостерігачу. Істотними ці зміни стають тоді, коли швидкість руху об'єкта наближається до швидкості руху світла. Для таких об'єктів час тече значно повільніше. Простір, як і час, може розширюватися і стискатися залежно від умов. Це вносить зміни в найбільш фундаментальні категорії, необхідні при описі реальності.

3 цього приводу Х. Ортега-і-Гассет у статті «Історичний сенс теорії Ейнштейна» стверджує, що 3 теорією відносності реальність «отримала» одну властивість - властивість перспективності. Це зауваження позбавляє розуміння теорії відносності як чогось суб'єктивного. Реальність існує не сама по собі, вона відкривається спостерігачеві в залежності від перспективи, з якої спостерігач на неї дивиться. Але це властивість самої реальності. Якщо якась властивість природи в одному випадку проявляється, а в іншому - ні, це не говорить про суб'єктивність глядача (важлива відмінність від уявлень Бора), це говорить, що ряд властивостей приховані і відкриваються в залежності від ситуації. 3 цього приводу іспанський філософ пише: «Справа в тому, що однією з особливостей реальності $€$ те, що вона має властивість перспективи, інакше кажучи, що реальність організовується по-різному, в залежності від місця, з якого вона розглядається» ${ }^{4}$.

Цікаво, що спільну рису в квантової теорії і теорії відносності щодо проблеми спостерігача і реальності відзначав також і Н.Бор в роботі «Проблема причинності в атомній фізиці»: «В обох випадках ми стикаємося 3 новими аспектами проблеми спостереження, що включають певний перегляд перелічених уявлень про фізичну реальність і що беруть початок у виявленні загальних законів природи, які не чинять безпосереднього впливу на повсякденний досвід» 5 .

Повернемося до Ейнштейна. Незважаючи на його великі відкриття, вони не дали йому відповідей, які він шукав. Можливо саме тому у Ейнштейна досить багато філософських текстів. Він намагався осмислити результати, досягнуті наукою. Але проблема полягала в тому, що з точки зору Ейнштейна, його теорія лише вносить певні штрихи в картину реальності, але не описує іiі цілком. За його ж власним (та його співавторів) критерієм, повною теорія вважається тоді, коли вона описує всі параметри. Однак, якщо всю фізику за часів Ньютона можна було звести до елементарних структур реальності (матеріальних точок), то в XX столітті чотири концепції (класична механіка, електродинамічна теорія, квантова механіка і теорія відносності) існували окремо кожна у своїй галузі, і при цьому залишалося незрозумілим, як саме вони поєднуються, і за якими законами працює цілісний Всесвіт.

\footnotetext{
${ }^{1}$ Айзексон, У. (2015). Эйнштейн. Его жизнь и его Вселенная. Москва: CORPUS, 371.

2 Эйнштейн, А. (1967). Собрание научных трудов в четырех томах. Москва: Наука, 87.

3 Там, само, 87.

${ }^{4}$ Ортега-и-Гасет, Х. (2005). Исторический смысл теории Эйнштейна. Эпистемология и философия науки, 4, 2, 223.

Cyberleninka.ru <https://cyberleninka.ru/article/n/istoricheskiy-smysl-teorii-eynshteyna/viewer>. (2021, лютий, 05).

${ }^{5}$ Бор, Н. (1965). Проблема причинности в атомной физике. Успехи физических наук, 147, 351.
} 
Тому ми можемо з упевненістю сказати, що у Ейнштейна до кінця його днів не було відповіді на питання, яка картина реальності правильна. Відомо, що він багато років працював над цим, намагався поєднати чотири наукові концепції, знайти для них єдиний фундамент. Треба сказати, проблема пошуку об’єднуючої теорії актуальна у фізиці і сьогодні. Нові технології і методи дозволяють вийти в розгляді проблеми на новий рівень. Спроби відкриття Гравітон (елементарної частинки гравітаційної взаємодії) тривають. Проводяться складні наукові експерименти, неможливі за часів життя Ейнштейна. Останнім словом фізики сьогодні $є$ так звана «теорія струн», - це спроба поєднати всі частини фізики і описати їх за допомогою теорії всього. (У С.Хокінга $є$ книга, яка називається «Теорія всього»). Однак «теорія струн» не може стати сьогодні предметом філософського осмислення і не тому, що ії коректність заперечується навіть у самій фізиці. Проблема полягає в тому, що на сьогоднішній день ії неможливо перевірити на практиці. Однак робота в цьому напрямку - це, безумовно, продовження справи усього життя Ейнштейна. Пошук теорії, яка описує реальність в повному обсязі (кожен її параметр точно), фундаментальне завдання, яке ставив перед собою Ейнштейн.

\section{Основні висновки.}

Підсумовуючи вище сказане, зазначимо декілька речей. Альберт Ейнштейн чітко розумів, що наявних у науці даних недостатньо для того, щоб описати повну картину реальності. Частково причиною цього служили недостатні технічні можливості, почасти - не розроблена наукова теорія. Відомо, що Ейнштейн багато років працював над так званою «теорією всього», він прагнув знайти у фізиці фундамент, який об’єднав би існуючі в різних сферах науки дані. I це, 3 точки зору філософського пізнання, можна було б назвати картиною реальності. Пошук такої теорії був «надзавданням» останніх років життя Ейнштейна.

Не випадково, що питання про реальність - філософське питання - виникало у вченого в полеміці з копенгагенської школою фізики. Коли Нільс Бор і його колеги запропонували настільки незвичну і несподівану для традиційного наукового підходу систему базових положень, Ейнштейн виявився в опозиції до них. Хоча він визнавав строгість наукового обгрунтування цієї теорії, іiі фундаментальних, по суті філософських, основ, він прийняти не міг. I з цих розбіжностей, що проявилися в багаторічній полеміці, ми можемо судити про реальність в поданні А. Ейнштейна. Хоч він і не був філософом і не зумів розробити своє уявлення в повній мірі, ці суперечки вказують на те, якою реальність, згідно з уявленнями Ейнштейна, не повинна бути. Оскільки він не приймав принцип невизначеності В. Гейзенберга, ми можемо зробити висновок, що одна з властивостей реальності (згідно з Ейнштейном) - наявність закону причинності як фундаментального принципу. Це ключовий момент. Реальність світу обов'язковим чином передбачає, що у кожної дії $є$ причина! Крім того, теорія, що описує реальність, повинна описувати всі параметри експерименту. Оскільки принцип невизначеності передбачає ймовірність того чи іншого параметра, ця теорія неповна за визначенням. Крім того, ми можемо стверджувати, що реальність у розумінні Ейнштейна ніяк не залежить від спостерігача, приладів і зовнішніх впливів.

Ще один важливий пункт уявлень великого фізика - об'єкти реальності обов'язково повинні бути розташовані в часі і просторі. У цьому положенні теж уявлення Ейнштейна про те, яка природа реальності. Ми знаємо, що теорія відносності змусила переглянути поняття простору і часу i, оскільки це фундаментальні категорії реальності, вони неминуче спричинили зміни в питанні про те, що таке реальність. Сам Ейнштейн був далекий від вирішення всіх проблем у цій галузі, але він поставив вектор для розвитку всієї теоретичної фізики, в тому числі й сучасної, інакше кажучи, поставив новий вектор пошуків реальності.

\section{References:}

1. Ayzekson, U. (2015). Eynshteyn. Yego zhizn i yego Vselennaya [Einstein. His life and his universe]. Kyiv: CORPUS. [in Russian].

2. Kassirer, E. (2009). Teoriya otnositelnosti Eynshteyna [Einstein's Theory of Relativity]. Moscow: Knizhnyy dom LIBROKOM. [in Russian].

3. Kuznetsov, B. G. (1972). Eynshteyn. Zhizn. Smert. Bessmertiye [Einstein. Life, Death, Immortality]. Moscow: Nauka. [in Russian].

4. Kumar, M. (2015). Kvant. Eynshteyn, Bor i velikiy spor o prirode realnosti [Kvant. Einstein, Bohr and the great debate about the nature of reality]. Moscow: AST. [in Russian].

5. Fok, V.A. Eynshteyn, A., Podolskiy, B. Y. (1936). Mozhno li schitat, chto kvantovo-mekhanicheskoye opisaniye fizicheskoy realnosti yavlyayetsya polnym? [Can we assume that the quantum-mechanical description of physical reality is complete?] Advances in Physical Sciences, 436-457. [in Russian]. 
6. Ortega-i-Gasset, J. (2005). Istoricheskiy smysl teorii Eynshteyna [The historical meaning of Einstein's theory]. Epistemologiya i filosofiya nauki, 4, 2, 323. [Epistemology and philosophy of science]. Cyberleninka.ru <https://cyberleninka.ru/article/n/istoricheskiy-smysl-teorii-eynshteyna/viewer>. (2021, February, 05). [in Russian].

7. Eynshteyn, A. (1967). Sobraniye nauchnykh trudov. V chetyrekh tomakh [Collection of scientific papers. In four volumes]. Moscow: Nauka. [in Russian].

8. Jagdish, M. (2000). Einstein physics and reality. World Scientific. [in English]. 